\title{
Effect of Intercropping Practices of Globe Artichoke (Cynara scolymus L.) with Garlic (Allium sativum L.), N-rates and Biofertilizers on Growth, Productivity, Land Equivalent Ratio and Microbiological Properties in Globe Artichoke Rhizosphere
}

\author{
U. M. Saif Eldeen *, A. S. Ezzat* and S. M. El-Kadi** \\ *Vegetable Research Department, Horticulture Research \\ Institute, Agricultural Research Centre, Cairo and ${ }^{* *}$ Agriculture \\ Microbiology Department, Faculty of Agriculture, Damietta \\ University, Damietta, Egypt.
}

\begin{abstract}
I NTERCROPPING is planting of two or more species that are simultaneous in a period of their growth cycle. Hence, the present study aimed to investigate the growth, yield, land equivalent ratio (LER) and various chemical and microbiological properties in rhizosphere of globe artichoke and green garlic grown in the field solely (PS) and intercropped (IS1 and IS2). The study was conducted in Baramoon Res. Sta., Mansoura, Egypt during the two seasons of 2012/13 and 2013/14. It also studied the effect of microbial inoculants and $\mathrm{N}$-fertilizer rates.
\end{abstract}

Results showed that there were growth and yield adaptability between globe artichoke and green garlic in intercropping. Treatment of IS1 (globe artichoke x garlic equal $4000 \times 42000$ plant fed $^{-1}$ ) with microbial inoculants (Azotobacter + Azospirillum) and $75 \mathrm{~kg} \mathrm{~N}^{-1}$ produced the highest yield as land equivalent ratios (LERs), it was the highest LERs (1.50) yield compare to sole culture, increased. The microbial populations were in the highest values with the same treatment IS1. Monocropping of globe artichoke or green garlic had detrimental effects on soil microbial communities. These findings indicate that intercropping globe artichoke with garlic could be an ideal farming system to effectively improve yield, quality, microbial activity and economics to develop sustainable globe artichoke production.

Keywords: Globe artichoke, Green garlic, Intercropping, Land equivalent ratios (LERs), Yield, Economics and Biofertilization.

Intercropping gives several advantages such as the exploitation of the place and time economically, increases the total production of the unit area, covers with consumer needs of the farmer, flows of income throughout the year and utilizes resources efficiently, in addition to many other advantages. Globe artichoke (Cynara scolymus L.) is mostly grown on a mono-cropping pattern in Egypt, 
which carries many problems with it, such as deterioration of soil physicochemical properties (Ye et al., 2004), adverse effects on soil structure (Huang et al., 2006) and the build-up of soil-borne diseases and autotoxicity (Ahmad et al., 2013). So mono-cropping system has negative impacts on the soil physical properties and structure, thus intercropping system is the better option to address these problems. Also, globe artichoke takes a long time in the field, about eight months, and sows in rows at 0.8 to $1.0 \mathrm{~m}$ apart and 1 to $1.2 \mathrm{~m}$ apart (large distance) and plant growth will be limited during the long growth periods (in the range of 3: 4 months), which requires farmers to look for suitable crop to grow with globe artichoke without reducing its final yield. Choosing different intercropping models of garlic with globe artichoke and soil inoculants are considered the target to provide farmers with scientific knowledge for achieving more land utilization and net return.

Intercropping is the practice of growing two or more crops in close proximity in the same growing season, aims to maximizing yield through synergistic interactions between different cultivated plants and promote efficient use of resources (Awal et al., 2006). Intercropping is now becoming more important to improve soil quality and increase crop productivity (Li et al., 1999). This cropping system is particularly significant in developing countries, where arable land is suppose to be limited.

Garlic (Allium sativum L.) is known for its antimicrobial components mainly allicin. The exudates secreted by the rooting system of garlic can cause pronounce effects on soil structure and ecology. Furthermore, it resulted in some significant impact on the growth patterns, yield and quality of intercropped plant (Ahmad et al., 2013, Wang et al., 2014). Hence intercropping of garlic with globe artichoke can be productive in overcoming problems created during continuous cropping system.

Garlic has effectively been incorporated into an intercropping system as a companion crop due to its allelopathic and antimicrobial effects. Some studies have reported that garlic intercropping can prevent insect attack (Mogahed, 2003, Lai et al., 2011) and weed invasion (Mueller et al., 1998). Recent research demonstrated that intercropping with garlic, green garlic (Xiao et al., 2012) and onion (Zhou et al., 2011) can alleviate problems associated with continuous cropping (soil sickness) of cucumbers under protected cultivation. However, most attention has been directed to the yield and growth parameters, as well as soil biological characteristics.

Studies showed that soil microbial diversity, soil enzyme activities and crop yield could be affected by land management practices (Carney et al., 2004, Acosta-Martinez et al., 2010). Intercropping is becoming more important in improving the utilization of land resources and increasing crop productivity ( $\mathrm{Li}$ et al., 2001). Some studies have demonstrated that intercropping can relieve soil sickness by improving soil quality (Ahmad et al., 2013) and the ecological microclimate (Olasantan, 1996). In addition, intercropping can effectively

Egypt. J. Hort. Vol. 42, No. 2 (2015) 
improve nutrient mobilization in the rhizosphere and nutrient acquisition based on inter-specific root interactions (Inal et al. 2007). Most studies on nutrient uptake and transfer have focused on legume-cereal intercropping systems (AduGyamfi et al., 2007). Nitrogen (N) input and transfer occurs in this intercropping system based on the specific biological nitrogen fixation of leguminous crops (Adu-Gyamfi et al., 2007). Some of rhizosphere microorganisms fix the atmospheric nitrogen (by symbiotic relationship with the plant or beneficial free living bacteria, Azotobacter and Azospirillum, which living in the soil), dissolve the phosphorus and potassium of the soil (Sturz and Christie, 2003), control plant stress, and protection plant diseases (Lugtenberg and Kamilova, 2009), stimulate the growth of plants by helping to control pathogenic organism (Vessey, 2003) and also, could provide defense against pathogen attack (Siddiqui, 2004). Plant growth promoting rhizobacteria (PGPR) are able to produce plant growth promoting substances and antibiotics (Haas and Défago, 2005). The uptake and mobilization of micronutrients is also influenced by intercropping, especially $\mathrm{Fe}$ in peanut and maize intercropping systems (Zheng et al., 2003). Except for legume-cereal intercropping systems, other studies reported that the turmeric, maize and onion intercropping systems improved nutrient uptake compared to that of either of the sole crops (Sivaraman and Palaniappan. 1996). In this respect, Zhou et al. (2011) demonstrated that intercropping cucumber with onion or garlic increased cucumber productivity and improved soil enzyme activities, soil bacterial and fungal community structures at different levels. Also, Song et al. (2007) indicated that intercropping (wheat/faba bean, wheat/maize, and maize/faba bean) had significant effects on microbiological and chemical properties in the rhizosphere, which may contribute to the yield enhancement by intercropping.

The long-term use of mineral fertilizers, particularly high rates of nitrogen fertilizers, may be harmful, as it leads to increase gaseous nitrogen losses, deteriorating physical, chemical and biological properties of the soil and, eventually, reduce safety of the plant products obtained (Barabasz et al., 2002). Accordingly, attention has been focused on the use of different organic substrates and biofertilizers (microbial inoculants) as an alternative and/or a supplement to costly mineral fertilizers (Sofi and Wani, 2007).

The objective of this research is to investigate the possibility of planting garlic with globe artichoke under different intercropping patterns and different $\mathrm{N}$-rates with soil amendments on growth, early and total yield, land equivalent ratio, microbial population and economic evaluation in globe artichoke.

\section{Materials and Methods}

\section{Plant materials and growth conditions}

The experiment was conducted during the two seasons of 2012/13 and 2013/14 in a clay loam soil at Baramoon experimental farm (latitude $30^{\circ} 11^{\prime} \mathrm{N}$, longitude $28^{\circ} 26^{\prime} \mathrm{E}$ and altitude $+7 \mathrm{~m}$ above sea level), Mansoura Hort. Res. Sta., 
Egypt. The soil contained $0.04 \%$ available N, $1.3 \%$ organic matter and $\mathrm{pH} 7.9$ (average two seasons). Extractable soil $\mathrm{P}$ and $\mathrm{K}$ levels in the plots used in this 2-year trial were in the range of 11.0 to $11.5 \mathrm{mg} \mathrm{kg}^{-1}$ for $P$ and 295 to $310 \mathrm{mg} \mathrm{kg}$ ${ }^{1}$ for $\mathrm{K}$. Local climate is hot and dry during the summer and warm in winter. Temperature range between a minimum average of $8.5^{\circ} \mathrm{C}$ at night and a maximum average of $40.2^{\circ} \mathrm{C}$ at day in summer (during the seasons of study). Globe artichoke cv. Green globe and garlic cv. Balady were used in this experiment.

\section{Experimental arrangement, treatments and crop management}

A split-plot design based on randomized complete blocks was used. Two intercropping systems plus sole crop were assigned to the main plots and the soil amendment treatments were devoted to the sub-plots. Treatments were replicated three times to make a total of 36 plots for one crop $(3 \times 4 \times 3)$.

Each experimental sub-plot consisted of 4 rows and each row was $4 \mathrm{~m}$ long and $1 \mathrm{~m}$ width. The old grown pieces (stumps) of globe artichoke were treated pre-planting with fungicides for 30 minutes. The planting dates were 15 and 19 of August in the $1^{\text {st }}$ and $2^{\text {nd }}$ seasons, respectively. Garlic was intercropped and planted during the $4^{\text {th }}$ and $5^{\text {th }}$ of September for both seasons. Nearly uniform cloves were soaked in running water for $12 \mathrm{~h}$ before planting. The preceding crop was maize in the two seasons.

Two intercropping models in which globe artichoke were intercropped with standing normal green garlic, in addition to two monoculture crops were used as follows:

- Intercropping system one (IS1): intercropping garlic with globe artichoke by planting globe artichoke in rides $1 \mathrm{~m}$ wide in hills spaced $1 \mathrm{~m}$ apart on one

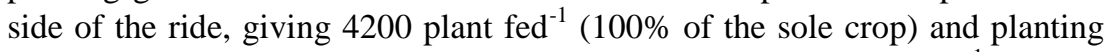
garlic on the other side in hills $10 \mathrm{~cm}$ apart to give 42,000 plant $^{-1} \mathrm{fe}^{-1}$ (30\% of the sole crop).

- Intercropping system two (IS2): intercropping garlic with globe artichoke by planting globe artichoke in rides $1 \mathrm{~m}$ wide in hills spaced $1 \mathrm{~m}$ apart on one

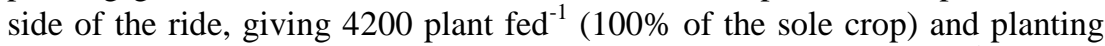
garlic on the other side in hills $15 \mathrm{~cm}$ apart to give 28,000 plant fed $^{-1}(20 \%$ of the sole crop).

- Pure stand of globe artichoke $\left(P S_{g a}\right)$ : stumps were hand-planted in rides $1 \mathrm{~m}$, width spaced $1 \mathrm{~m}$ apart between pieces $\left(1.0\right.$ plant $\left.\mathrm{m}^{-2}\right)$, giving 42000 plant fed $^{-1}$.

- Pure stand of green garlic $\left(P S_{g g}\right)$ : cloves were hand-planted on both sides of the ridges $(60 \mathrm{~cm})$ at $10 \mathrm{~cm}$ apart $\left(16.67\right.$ plant $\left.^{-2}\right)$, giving 140,000 plant $\mathrm{fed}^{-1}$.

Four soil amendments were compared as nitrogen $\mathrm{N}$ at a rate of $100 \mathrm{~kg}^{-1}$ (control), microbial inoculants (Azotobacter and Azospirillum), microbial inoculants $+75 \mathrm{~kg} \mathrm{~N}^{-1}$ and microbial inoculants $+50 \mathrm{~kg} \mathrm{~N}^{-1} \mathrm{fed}^{-1}$. Nitrogen fertilizer (ammonium sulphate $20.5 \% \mathrm{~N}$ ) was added at two equal doses, i.e., the

Egypt. J. Hort. Vol. 42, No. 2 (2015) 
first with $1^{\text {st }}$ irrigation, and the second with $3^{\text {rd }}$ irrigation. The rate of biofertilizers inoculation was $5 \mathrm{ml}$ of each culture for each plant, as sub-soil, in the rhizosphere area with $2^{\text {nd }}$ irrigation (Selim and El-Saei, 2001). All treatments received the same total amount of phosphorus $\left(75 \mathrm{~kg} \mathrm{fed}^{-1}\right)$ and potassium $\left(96 \mathrm{~kg} \mathrm{fed}^{-1}\right)$ fertilizer for the season, which were applied with nitrogen application. All the recommended cultural practices for growing both crops were performed when it was necessary.

\section{The source of microorganisms and the inocula preparation}

Two active bacterial isolates were used in this study. Azotobacter chroococcum and Azospirillum lipoferum were isolated from rhizosphere of onion plants and identified in Agricultural Microbiology Department, Fac. Agric., Damietta Univ., Damietta, Egypt. A. chroococcum and A. lipoferum were maintained on a modified Ashby's medium (Abdel-Malek and Ishac, 1968) and modified nitrogen-deficient semi-solid makate medium (Dobereiner, 1978), respectively at $5^{\circ} \mathrm{C}$.

Inocula were prepared by subculturing of A. chroococcum and A. lipoferum mother culture on $100 \mathrm{ml}$ of sterilized modified Ashby's medium and modified nitrogen-deficient semi-solid makate medium, respectively in $250 \mathrm{ml}$ conical flasks and incubated at $30^{\circ} \mathrm{C}$ for 10 days on a rotary shaker at $160 \mathrm{rpm}$. The cultures were counted and the count was corrected by adding sterilized water to give the final count (1x108 cell/ $/ \mathrm{ml})$. The rate of biofertilizers inoculation was $5 \mathrm{ml}$ of each culture for each plant, as sub-soil, in the rhizosphere area (Selim and El-Saei, 2001).

\section{Data and measurements}

Globe artichoke: After 120 days from planting date, five samples of plant shoots from each sub-plot were taken and oven-dried at $60^{\circ} \mathrm{C}$ for $72 \mathrm{~h}$ and foliage dry weight per plant was determined. All flower heads of plants in each plot were harvested during the periods from November-February and MarchMay, to study yield distribution and to determine early and total yields. At harvest time, samples of receptacle in dry weight were analyzed for inulin and nitrogen content according to Winton and Winton (1958) and Bremner (1965) using a semi-micro Kjeldahl apparatus, respectively.

Green garlic: A random sample of ten plants was taken from each plot after 120 days from planting to estimate plant dry weight, bulb weight and bulb diameter. At 150 days from planting, plants in the two central rows of each plot were weighed in $\mathrm{kg}$ and converted to record as total yield (ton/fed). Samples of the dried cloves were ground, wet digested and determined $\mathrm{N}$ content (Bremner, 1965).

Land equivalent ratios: $\mathrm{LER}=\mathrm{L}_{\mathrm{A}}+\mathrm{L}_{\mathrm{B}}=\mathrm{Y}_{\mathrm{A}} / \mathrm{S}_{\mathrm{A}}+\mathrm{Y}_{\mathrm{B}} / \mathrm{S}_{\mathrm{B}}$

$\mathrm{L}_{\mathrm{A}}$ and $\mathrm{L}_{B}$ are the LERs for the individual crops (globe artichoke and green garlic). $Y_{A}$ and $Y_{B}$ are the individual crop yields in intercropping, where $S_{A}$ and $S_{B}$ are their yields as sole crops.

Economic evaluation: Total yield of globe artichoke and green garlic of intercrops as compared with sole crop were recorded at harvest and cost benefit ratio worked out. 
Nitrogenase activity and microbial population count of soil samples

The nitogenase activity of two bacterial isolates (A. chroococcum and A. lipoferum) was determined using the acetylene reduction assay (Hardy et al., 1973) in National Center for Agric. Res. in El-Dokki, Giza, Egypt. Values of nitrogenase activity were recorded as $\mathrm{n}$ moles $\mathrm{C}_{2} \mathrm{H}_{4} / \mathrm{ml} / \mathrm{h}$.

Poured plate method was used to determine the total bacterial count and the total yeast and fungi count. Total bacterial count of soil samples were determined according to (APHA, 2009) using nutrient agar medium (Difco, 2009). After inoculation all plates were incubated at $30^{\circ} \mathrm{C}$ for 3 days before counting. Total yeast and fungi count of soil samples were determined using potato dextrose agar (PDA) medium (Oxoid, 2006). The plates were incubated at $25^{\circ} \mathrm{C}$ for 6 days. After the incubation period, developed colonies were counted per each plate. The mean count of colonies on plates was recorded to represent fungal count (APHA, 2009). Most probable numbers (MPN) technique was used to determine the count of A. chroococcum and A. lipoferum. Three decimal dilutions for each sample in three replicate tubes were employed. The number of positive tubes was recorded. The count of bacteria per gram of soil sample was calculated from standard table according to Sutton (2010). A. chroococcum and A. lipoferum counts of soil samples were determined on modified Ashby's medium (Abd ElMalek and Ishac, 1968) and modified nitrogen-deficient semi-solid makate medium (Dobereiner, 1978), respectively, and incubated at $30^{\circ} \mathrm{C}$ for 10 days.

\section{Statistical analysis}

Data were analyzed by ANOVA and the difference of the treatments was compared using the least significant difference (LSD) test at $P \leq 0.05$ according to Snedecor and Cochran (1989).

\section{Results and Discussion}

The effect of intercropping with green garlic and soil amendments on the biomass, yield and chemical composition of globe artichoke

The interaction effect between intercropping patterns and soil inoculants, had significant differences on shoot dry weight per plant, early yield, total yield, inulin and $\mathrm{N}$ contents (receptacle) of globe artichoke, in both seasons (Table 1 and Fig. $2 \& 3)$. Globe artichoke pure stand ( $\mathrm{PS}_{\mathrm{ga}}$ ) or intercropped to green garlic IS1 with $100 \mathrm{~kg}$ or $75 \mathrm{~kg} \mathrm{~N}$ plus Azotobacter and Azospirillum inoculants exhibited significant positive effects on shoot biomass compared with other treatments. Significant positive effects of globe artichoke $\mathrm{PS}_{\mathrm{ga}}$ or garlic intercropping IS1 and $100 \mathrm{~kg}$ or $75 \mathrm{~kg} \mathrm{~N}$ plus Azotobacter and Azospirillum inoculants were recorded on total yield, inulin and $\mathrm{N}$ content, in the two seasons of growth (Table 1). Also, IS2 with $100 \mathrm{~kg}$ or $75 \mathrm{~kg} \mathrm{~N}$ plus microbial inoculants had a significant effect on total yield per feddan. A significant effect of globe artichoke solely (in both seasons) or intercropped with green garlic ( $1^{\text {st }}$ season only) on early yield of globe artichoke was observed in Table 1. 


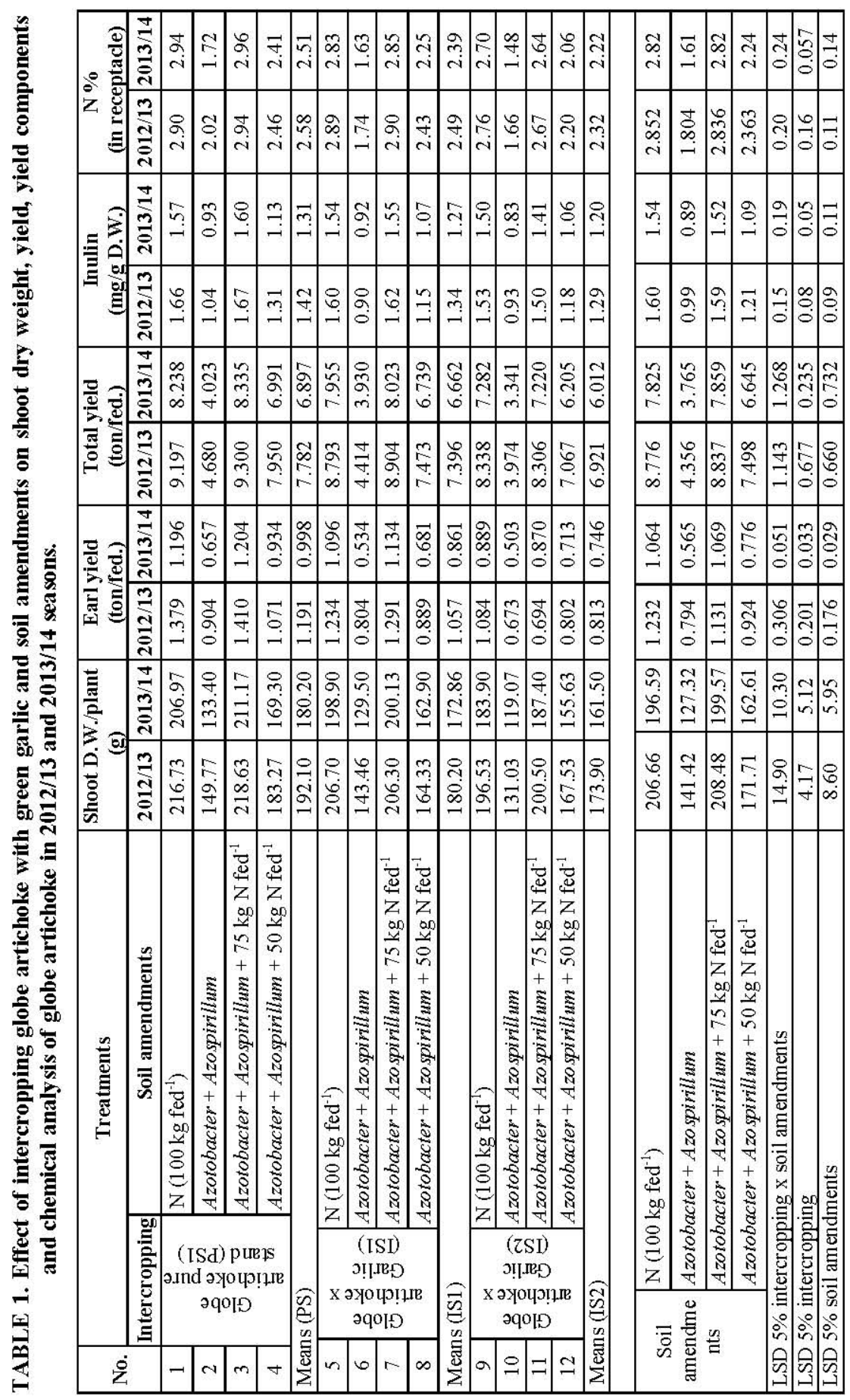

Egypt. J. Hort. Vol. 42, No. 2 (2015) 
Treatments:

1. IS1 x N (100 kg fed $\left.{ }^{-1}\right)$ 2. IS1 x Azotobacter + Azospirillum 3. IS1 1 Azoto. + Azosp. + $75 \mathrm{~kg} \mathrm{~N}$ 4. IS1x Azoto. + Azosp.+ $50 \mathrm{~kg} \mathrm{~N}$

5. IS2 x N $\left(100 \mathrm{~kg} \mathrm{fed}^{-1}\right)$ 6. IS2 $\mathrm{x}$ Azoto. + Azosp. 7. IS $2 \mathrm{x}$ Azoto. + Azosp. $+75 \mathrm{~kg} \mathrm{~N} 8$.

IS2x Azoto. + Azosp. $+50 \mathrm{~kg} \mathrm{~N}$

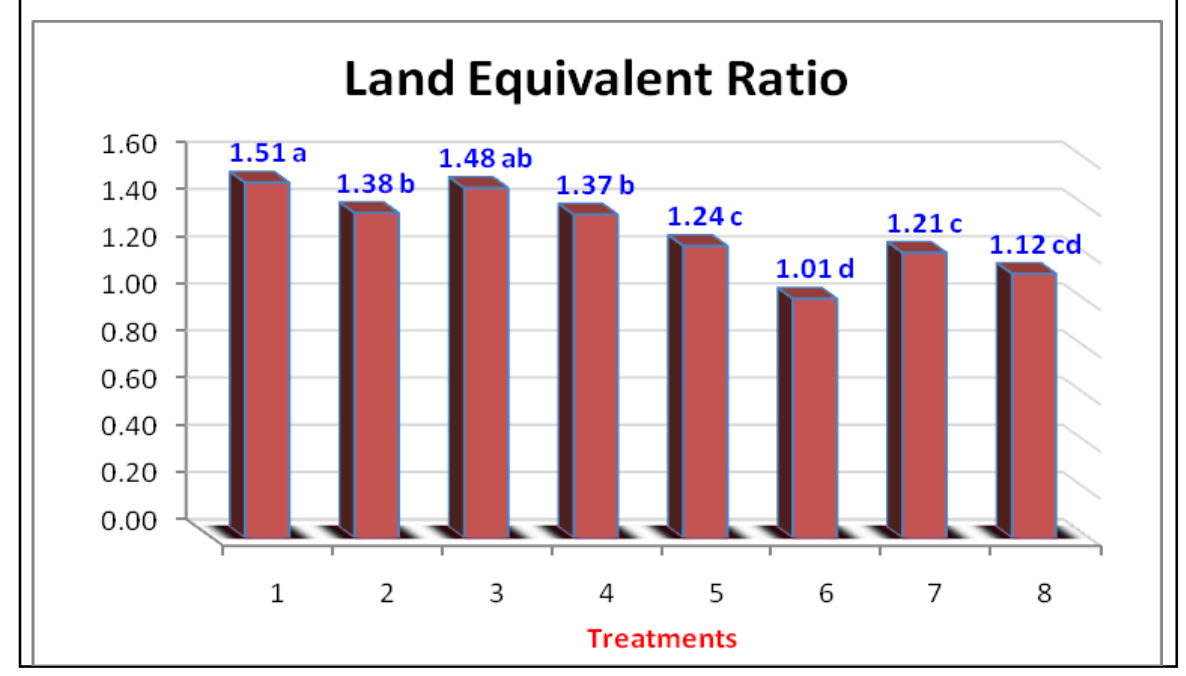

Fig. 1. Effect of intercropping globe artichoke with green garlic and soil amendments on land equivalent ratio LER in average of 2012/13 and 2013/14 seasons.
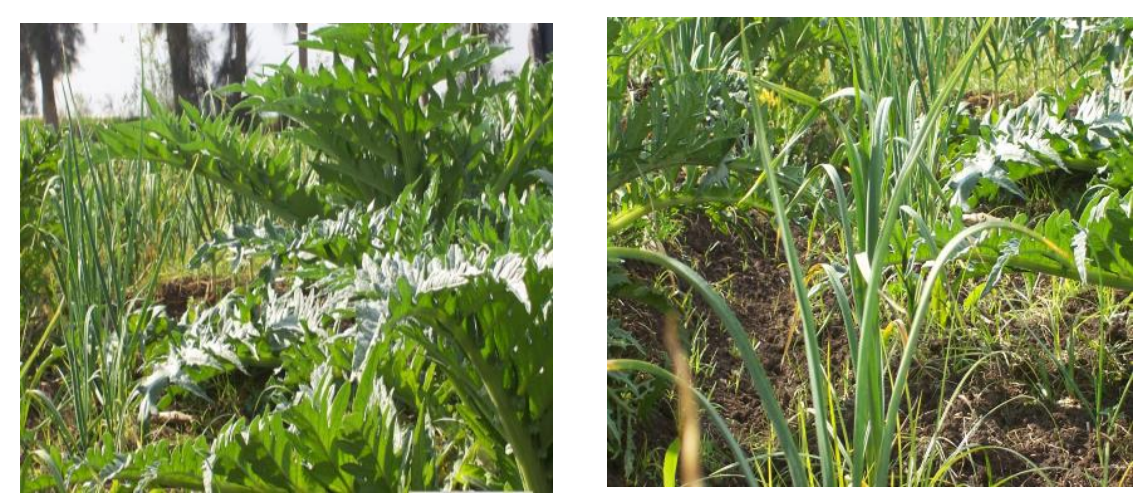

Fig. 2 and 3. Globe artichoke-green garlic intercropping (Baramoon Experi. Farm, H. R. I.).

When intercropping systems were kept constant, soil amendments had a significant effect on biomass, yield and chemical composition. Application of $\mathrm{N}$ at $100 \mathrm{~kg}$ or $75 \mathrm{~kg} \mathrm{~N}$ plus Azotobacter and Azospirillum inoculants exhibited significant positive effects on these parameters compared with other both treatments (Table 1).

No significant differences were detected in total yield and inulin content between pure stand $\mathrm{PS}_{\mathrm{ga}}$ and IS1 on globe artichoke treatments in both seasons (Table 1).

Egypt. J. Hort. Vol. 42, No. 2 (2015) 
These pronounced positive effects on the shoot biomass, total yield, inulin content and $\mathrm{N}$ concentration on globe artichoke plants may be attributed to the fact that plants under intercropping system markedly changed the population of soil microbial communities (Table 3). Intercropping with green garlic increased the concentration of bacteria and fungi in the rhizosphere as compared to monocropping. This may be due to the interaction of soil microorganisms and root exudates (garlic), which may affect soil microbial communities (Table 3). Previous studies showed that the amount and kind of root exudates differ between plant species, and these differences can stimulate species specific shifts in the soil microbial community (Uren, 2000). Root exudates contain root-specific metabolites that might have critical ecological impacts on soil macro and micro biota as well as on the whole plant. Through the exudation of a wide variety of compounds, roots affect the soil microbial community in their immediate vicinity, supporting beneficial symbioses, alter the chemical and physical properties of the soil, and inhibit the growth of competing plant species (Bertin et al., 2003). Our results (Table 1 and 3) are also in agreement with Keswani et al. (2003), who stated that intercropping increased the bacterial rhizosphere soil ratio of maize and soybean, whereas fungi rhizosphere soil ratio showed a decrease in both cases when compared to sole crop condition. Functional diversity and metabolic activity of soil microbial community improved under intercropping. Intercropping could significantly increase the quantity of soil bacteria in both maize and peanut root areas (Lixuan et al., 2007, Zhang et al., 2009). As demonstrated by Wu et al. (2010) that intercropping aromatic plants in sandy soil in pear orchard had good regulatory effects on the soil microbial quantity. In another study conducted by Chai et al. (2005) that intercropping significantly enhanced the number of total microbial population in the rhizosphere as compared to monoculture cropping. Also, Ahmad et al. (2013) concluded that intercropping pepper with green garlic improved soil microbial and biochemical properties as compared to monocropping.

The effect of intercropping with green garlic and soil amendments on the dry weight, yield, bulb characteristics and N-chemical composition of garlic

The interaction effect between globe artichoke intercropped with green garlic and soil amendments had significant effects on the dry weight of plant, bulb characteristics, yield and $\mathrm{N}$-nutrient element in the green garlic plants (Table 2).

Intercropping IS1 with soil amendments (N at $100 \mathrm{~kg}$ or $75 \mathrm{~kg} \mathrm{~N}$ plus Azotobacter and Azospirillum inoculants) of globe artichoke-green garlic and garlic pure stand $\mathrm{PS}_{\mathrm{gg}}$ had significant effect on bulb weight, bulb diameter and $\mathrm{N}$ concentration of green garlic plants. Only green garlic $\mathrm{PS}_{\mathrm{gg}}$ exhibited a significant effect on plant dry weight compared with other treatments, in both seasons. The dynamic change in total yield of green garlic due to intercropping presented in Table 2 and it showed that garlic $\mathrm{PS}_{\mathrm{gg}}$ and $\mathrm{N}(100 \mathrm{~kg})$ or $\mathrm{N}(75 \mathrm{~kg})$ plus Azotobacter and Azospirillum inoculants had a significant effect on total yield, in both seasons. 
When intercropping systems were kept constant and soil amendments varied, it was observed that $\mathrm{N}$ amendments at $100 \mathrm{~kg}$ or $75 \mathrm{~kg}$ plus soil inoculants with Azotobacter and Azospirillum had significant effect on all studied growth and yield as well as bulb quality parameters, in both seasons (Table 2).

Only pure stand of green garlic PS increased significantly the dry weight, yield, bulb characteristics and N-content of garlic in both seasons of study.

Garlic intercropped with their abundant nutrients increase the input of nutrient compared to the monocrop ( $\mathrm{N}$ content, Table 2 ). The increases in growth and yield of green garlic could be related to soil organic matter (green garlic produced numerous roots, which may be remained as a carbon source in the soil after harvesting) and available nutrients (Wang et al., 2014). In our experiment, it was found that enhancement of growth and yield of green garlic under intercropping system may be due to better availability of plant nutrients and root exudates from garlic plants (Ahmad et al., 2013, Wang et al., 2014). These results are supported by Zhou et al., (2007) that garlic root exudates significantly increased the chlorophyll content of the tested vegetables due to better absorption of nutrients in intercropped treatments. Also, Olga et al., (2007) showed that when tomato plants intercropped with marigold resulted in higher $(p \leq 0.05)$ net photosynthetic rate and chlorophyll content as compared to the control. Dong et al., (2008) reported that concentration of $20 \mathrm{mg} \cdot \mathrm{ml}^{-1}$ of garlic bulb aqueous extracts promoted peroxidase (POD) and catalase (CAT) activities, while higher concentrations inhibited POD and CAT activities. It is known that, Catalase is an enzyme of the anti-oxidant system and it prevents accumulation of $\mathrm{H}_{2} \mathrm{O}_{2}$ in the cells. It has been demonstrated that CAT activity can be induced in plant species (Jumin and Jin, 2010). Peroxidase plays role in auxin catabolism, production and breakdown of hydrogen peroxide. The anti-oxidant capabilities of POD make it as an important factor in the integrated defense response of plants to a variety of stresses (Cipollini, 1998). The inoculation with Azotobacter and Azospirillum plus nitrogen fertilizers under intercropping systems enhanced root elongation, surface area and changes root morphology, root dry weight, phytohormones and auxins production as compared with non-inoculated under monocultures, which improve the growth of entire root system, which results in enhanced mineral and water uptake (Ahmad et al., 2013).

The effect of intercropping globe artichoke with green garlic and soil amendments on land equivalent ratio LERs

The productivity of globe artichoke-garlic mixture and land equivalent ratios (LERs) were assessed in terms of yield production throughout the two growing seasons (Figure 1). Results showed that the LERs values of yields both globe artichoke-garlic mixture substantially exceeded that of their corresponding monoculture. Treatments of IS1 with $100 \mathrm{~kg}$ or $75 \mathrm{~kg} \mathrm{~N}$ plus microbial inoculants (Tables 1 and 3) had significant effect on LERs compared with other treatments. Calculating the land equivalent ratio (LERs) 1.51 and 1.48 were observed, respectively.

Egypt. J. Hort. Vol. 42, No. 2 (2015) 


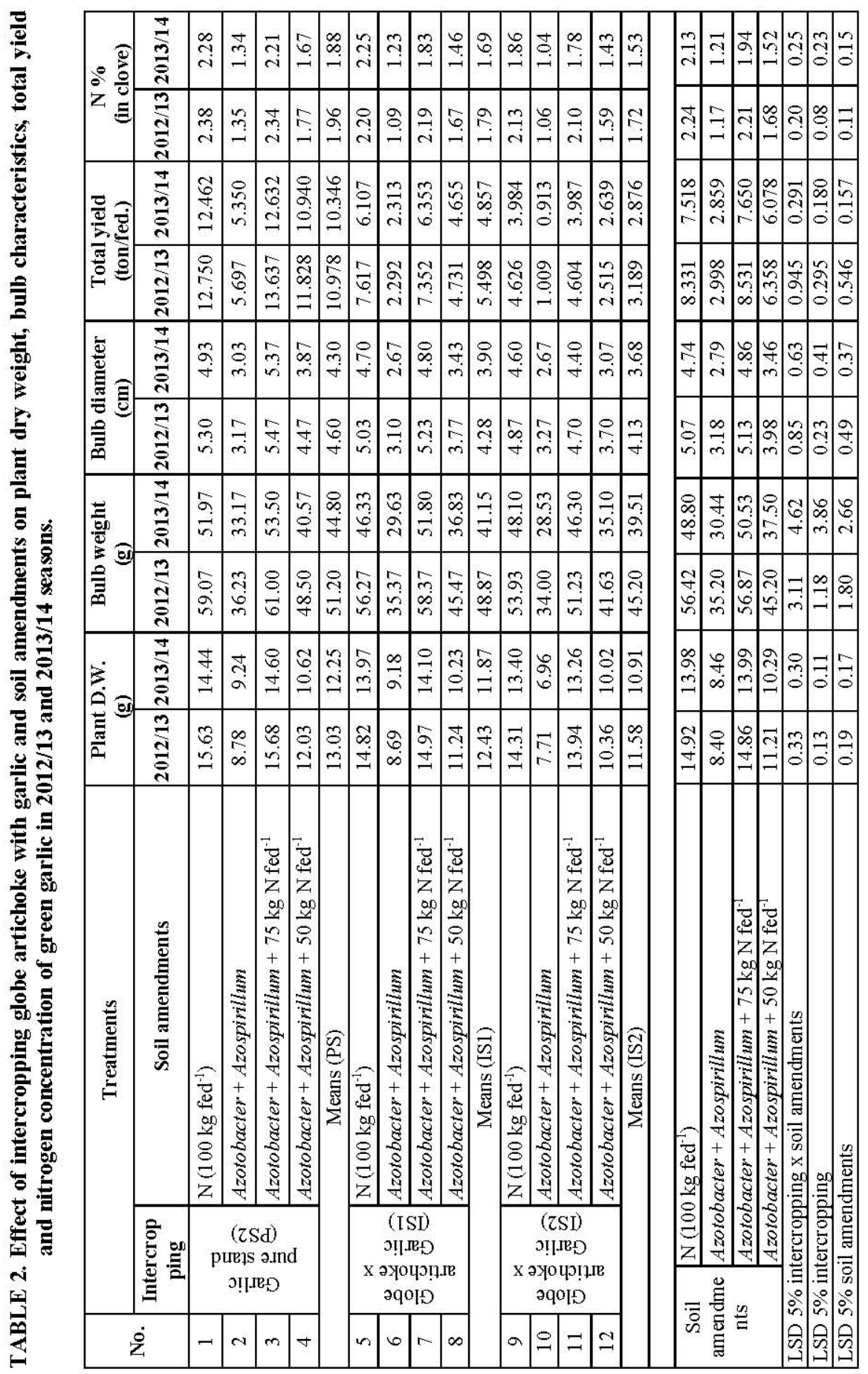

Egypt. J. Hort. Vol. 42, No. 2 (2015) 


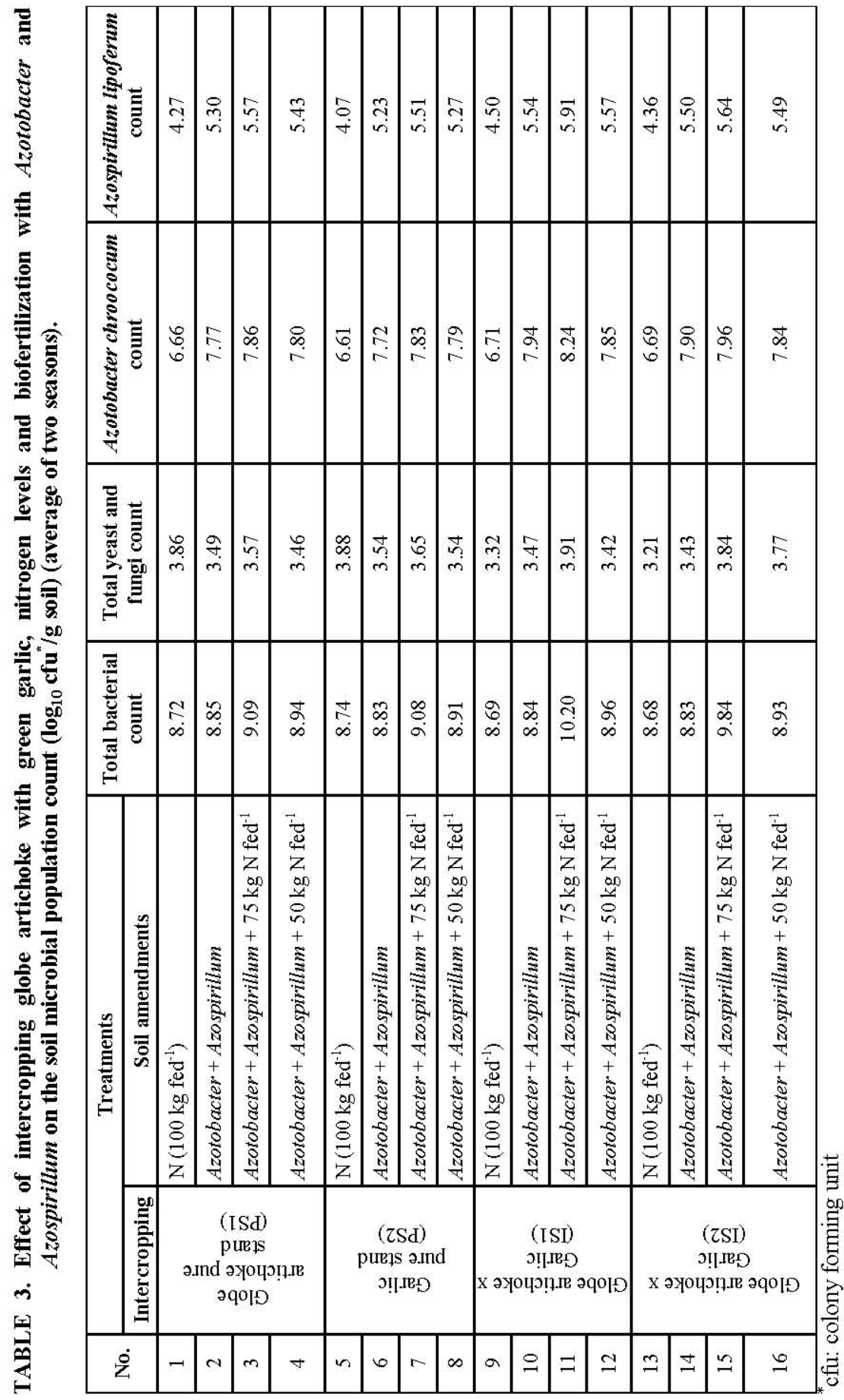

Egypt. J. Hort. Vol. 42, No. 2 (2015) 
Since the idea of land equivalent ratio in most cases, is the most important comparison between yield of the main crop in mixture and its yield in pure stand, it is rather expected that the combination of component species in mixture will be more productive than the species grown as a sole crops.

The result obtained were strongly coincided with the definition of land equivalent ratio in that the combination of component species in the mixture were more productive than the same species when grown as sole crops. However, the LER ratio, in almost all cases, was greater (over one) than the sole which interpreted as advantage of mixture over sole (Figure 1). Similarly, Mazaheri and Overysi (2004) documented that an LER of 1.0 or less indicating that no difference in yield between the intercrop and the collections of monoculture, while any value greater than 1.0 indicates that yield advantage for intercropping. Moreover, Dariush et al. (2006) confirmed that LER is taken as a measure of relative yield advantage for example LER of 1.2 indicates that the area planted to monocultures would need to be $20 \%$ greater than the area planted to intercrop to produce the same combined yields (i.e. $20 \%$ more land would be required as a sole crop to produce the same yield as intercropping). In addition, Ressende in 2000 could reach lettuce and radish intercropping more beneficial to obtain pure cultures and LER of intercropping 2.30 has been reported (Ressende et al. 2000). Mix garlic and beans culture, its usefulness in pure culture showed 2.80 LER (Lameei hervan, 2003).

The effect of intercropping globe artichoke with green garlic and soil amendments on microbial population

Nitrogenase is the enzyme used by some microorganisms to fix atmospheric nitrogen $\left(\mathrm{N}_{2}\right)$. The nitogenase activity was determined using the acetylene reduction assay, the values of nitrogenase activity were 6995.8 and $59.634 \mathrm{n}$ moles $\mathrm{C}_{2} \mathrm{H}_{4} / \mathrm{ml} / \mathrm{h}$ for Azotobacter chroococcum and Azospirillum lipoferum, respectively. Our results was similar to Mahmoud et al. (2011) who reported that, the nitrogen fixing bacteria (Azotobacter and Azospirillum) which isolated from onion rhizosphere resulted a highly active of nitrogenase and so the microorganisms should be used as active biofertilizer.

Table 3 show the effect of soil addition in the globe artichoke pure stand $\left(\mathrm{PS}_{\mathrm{ga}}\right)$ on the soil microbial population. The highest value of total bacterial count (9.09 $\log _{10} \mathrm{cfu} / \mathrm{g}$ soil) was achieved with Azotobacter + Azospirillum $+75 \mathrm{~kg} \mathrm{fed}^{-}$ ${ }^{1}$, but the lowest value $\left(8.72 \log _{10} \mathrm{cfu} / \mathrm{g}\right.$ soil) was done when $100 \mathrm{~kg}$ nitrogen / fed. Total yeast and fungi count average from 3.46 to $3.86 \log _{10} \mathrm{cfu} / \mathrm{g}$ soil. The present of fungi in the soil produce organic acids which increase the availability of nutrients and mineral for plants to absorb and uptake. The highest values of $A$. chroococum count and A. lipoferum count was in the treatment No. 3 being 7.86 and $5.57 \log _{10} \mathrm{cfu} / \mathrm{g}$ soil, respectively, on the other hand, the lowest values was in the treatment No. 1 being 6.66 to $4.27 \log _{10} \mathrm{cfu} / \mathrm{g}$ soil, respectively. Our results were agreement with Ghazal et al. (2011) who study the response of wheat plants to EM (Effective Microorganisms) and they found that, the high 
count of fungi $\left(36.33 \times 10^{2} \mathrm{cfu} / \mathrm{g}\right.$ soil) in the soil did not have any effect on the nitrogen fixer bacteria.

The observations of Abd El-Fattah (2001) may be explained why this value was high in the present of Azotobacter and Azospirillum. They reported that, the inoculation with Azotobacter and Azospirillum enhanced root elongation, surface area and changes root morphology, root dry weight, phytohormones and auxins production as compared with non-inoculated, which improve the growth of entire root system, which results in enhanced mineral and water uptake. They also added that, the presence of Azospirillum help plants to overcome the stress.

Table 3 also shows that, the effect of soil additions in the garlic pure stand $\left(\mathrm{PS}_{\mathrm{gg}}\right)$ on the soil microbial population. The values of total bacterial count, total yeast and fungi count, A. chroococum count and A. lipoferum count take the same trend with the above experiment. The highest values were achieved with Azotobacter + Azospirillum $+75 \mathrm{~kg} \mathrm{fed}^{-1}$, but the lowest values were obtained when $100 \mathrm{~kg} \mathrm{~N} \mathrm{fed}^{-1}$.

The effect of soil amendments in the globe artichoke $\mathrm{x}$ garlic (IS1) on the soil microbial population were also, presented in Table 3 . The maximum values of total bacterial, total yeast and fungi count, $A$. chroococum count and A. lipoferum count were archived when Azotobacter + Azospirillum $+75 \mathrm{~kg} \mathrm{fed}^{-1}$ was used being $10.20,3.91,8.24$ and $5.91 \log _{10} \mathrm{cfu} / \mathrm{g}$ soil. But the lowest values were $8.69,3.32,6.71$ and $4.50 \log _{10} \mathrm{cfu} / \mathrm{g}$ soil in the case of $100 \mathrm{~kg} \mathrm{~N} \mathrm{fed}^{-1}$.

This observation may be explain by the following, plant growth-promoting rhizobacteria (PGPR) and fungi can facilitate plant growth indirectly by reducing plant pathogens, or directly by facilitating the uptake of nutrients from the environment, by influencing phytohormone production (e.g. auxin, cytokinin, or giberallin), and/or by enzymatic lowering of plant ethylene levels. In addition to facilitating the growth of plant, plant growth-promoting microorganisms can protect plants from the deleterious effects of some environmental stresses including flooding, drought, salt and phytopathogens. Plant growth-promoting bacteria were tested on growth of tomato, pepper, canola, bean and lettuce under salt stress, and these biological treatments ameliorated the deleterious effect of salinity (Yildirim et al., 2006).

Many authors explain this observation as following, Azospirillum release broad-spectrum of plant growth regulator, i.e. auxins, gibberellins and cytokinins (El-Khawas, 1995). A. brasilense produced high quantities of indole-3-acetic acid (IAA) and tryptophol. IAA might have a positive effect on host growth due to production of plant growth substances (El-Khawas et al., 2000). Interactions between Azospirillum sp. and many plant species under saline stress have yielded contradictory evidence, some interactions were beneficial and some were somewhat negative (Bacilio et al., 2004).

Egypt. J. Hort. Vol. 42, No. 2 (2015) 
The effect of a biofertilizer (a mixture of growth promoting of non-symbiotic $\mathrm{N}$-fixing bacteria of genera Azotobacter, Azospirillium and Klebsiella) on growth, yield, quality and storability of two garlic (Allium sativum L.) cultivars was studied by Abdel-Razzak and El-Sharkawy (2013) and they found that, the treatment with biofertilizer result increasing and improvement in the garlic bulbs yield and quality as well as bulbs storability.

The effect of soil amendments in the globe artichoke $\mathrm{x}$ garlic (IS2) on the soil microbial population were also take the same pattern of the above experiment (Table 4), where the values of total bacterial count, total yeast and fungi count, A. chroococum count and A. lipoferum count were in the highest values with Azotobacter + Azospirillum $+75 \mathrm{~kg} \mathrm{fed}^{-1}$ was added, but the lowest values were resulted when $100 \mathrm{~kg}$ nitrogen/fed was applied. Our results were in the same line with those Selim and El-Saei (2001) who studied the effect of composed inoculation with $\mathrm{N}_{2}$-fixing bacteria and vesicular-arbuscular mycorrhiza on growth and nutrition of Mung bean and that found that, the highest numbers of total bacterial count was $22.77 \times 10^{6} \mathrm{cfu} / \mathrm{g}$ soil and Azospirilla was $65.61 \times 10^{4}$ $\mathrm{cfu} / \mathrm{g}$ soil in the soil inoculated with triple inocula in the presence of $1 / 2$ dose of nitrogen fertilizer.

The effect of intercropping globe artichoke with green garlic and soil amendments on economic evaluation

The economic evaluation of the results reveal that the globe artichoke-green garlic mixed culture IS1 and $\mathrm{N}$ at a rate of $75 \mathrm{~kg} \mathrm{fed}^{-1}$ with microbial inoculants (Azotobacter and Azospirillum) show the highest net return (£.€ 11,136 fed ${ }^{-1}, 1$ £.€ $=0.13 \$$ and 1 feddan $=0.42$ hectare), in comparison with other treatments. Thus, this treatment proved to be economical for intercropping production. As a support for the present results, Amanullah et al. (2006) indicated that one possibility for lowering the cost of planting would be the use of intercropping practices.

\section{Conclusion}

It is of great importance to take advantage of intercropping in the efforts for maintaining biodiversity and sustainable agricultural development. During this study globe artichoke and garlic based intercropping system improved physiological properties of globe artichoke. Also, we can concluded that intercropping of globe artichoke with green garlic and the application of $\mathrm{N}$ at 75 $\mathrm{kg} \mathrm{fed}^{-1}$ as well as microbial inoculants with Azotobacter and Azospirillum had good impact on growth, yield, land equivalent ratios and various chemical and microbiological prosperities of globe artichoke. Globe artichoke intercropped with green garlic recorded the highest net profit for small farmers. 


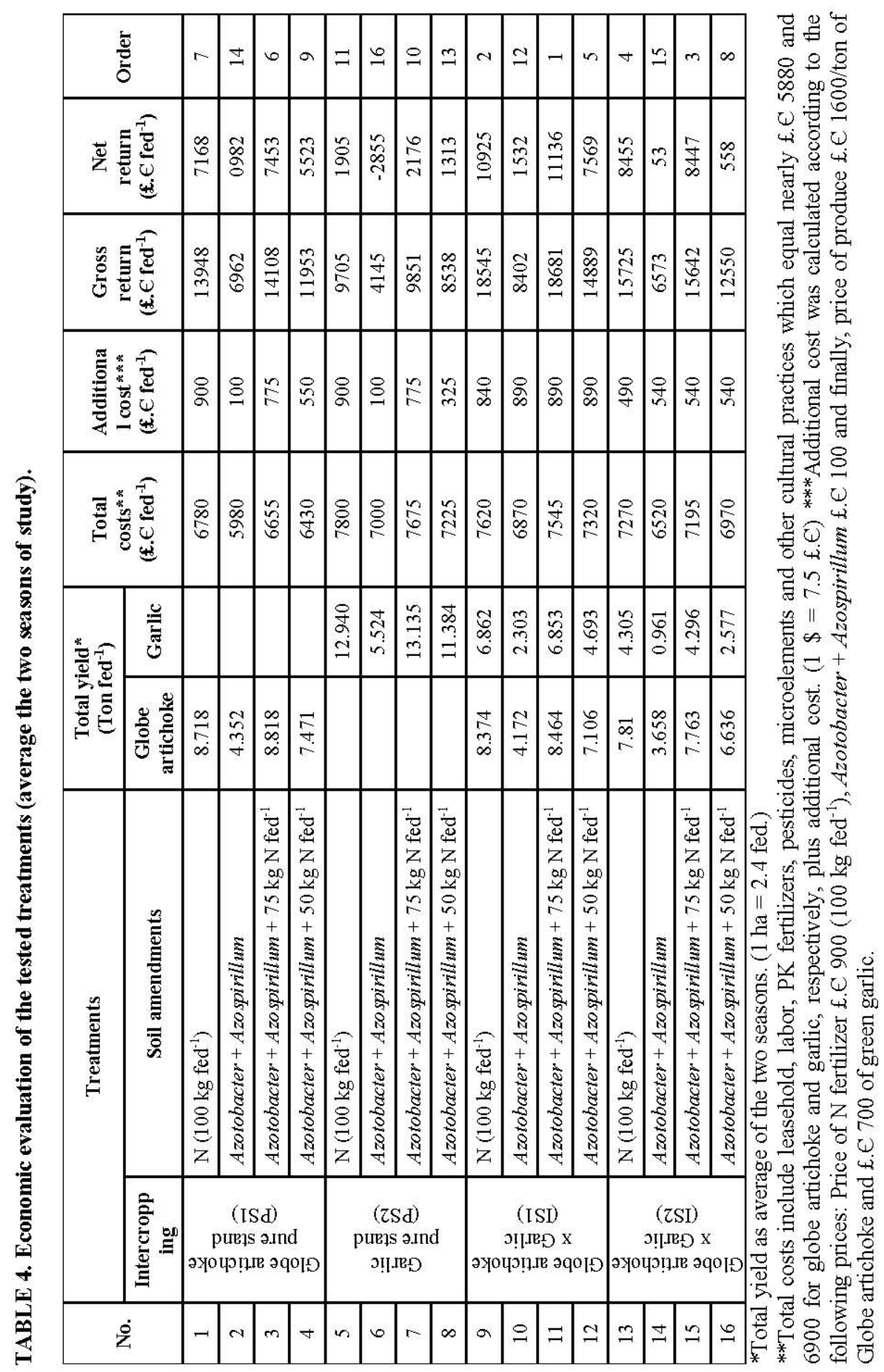

Egypt. J. Hort. Vol. 42, No. 2 (2015) 
References

Abd El-Fattah, F.K. (2001) Stimulatory effect of Azospirillum and Azotobacter on symbiotic efficiency between Bradyrhizobium and soybean under different rates of nitrogen fertilization. J. Agric. Sci. Mansoura Univ., 26 (6), 3961-3973.

Abd-El-Malek, Y. and Ishac, Y.Z. (1968) Evaluation of methods used in counting Azotobacter. J. Appli. Bacteriol., 31, 267-275.

Abdel-Razzak, H.S. and El-Sharkawy, G.A. (2013) Effect of biofertilizer and humic acid applications on growth, yield, quality and storability of two garlic (Allium sativum L.) cultivars. Asian J. Crop Sci., 5 (1), 48-64.

Acosta-Martínez, V., Burow, G. Zobeck, T.M. and Allen, V.G. (2010) Soil microbial communities and function in alternative systems to continuous cotton for the Texas high plains. Soil Sci. Soc. Amer. J., 74 1181-1192.

Adu-Gyamfi, J.J., Myaka, F.A., Sakala, W.D., Odgaard, R. and Vesterager, J.M. (2007) Biological nitrogen fixation and nitrogen and phosphorus budgets in farmermanaged intercrops of maize-pigeonpea in semi-arid southern and eastern Africa. Plant Soil, 295, 127-136.

Ahmad, I., Cheng, Z., Meng, H., Liu, T., Wang, M., Ejaz, M. and Wasila, H. (2013) Effect of pepper-garlic intercropping system on soil microbial and bio-chemical properties. Pak. J. Bot., 45 (2), 695-702.

APHA, American Public Health Association (2009) "Standard Methods For The Examination of Water and Wastewater", $20^{\text {th }}$ ed. APHA, Inc. New York.

Amanullah, M.M., Yassin, M.M., Vaiyapuri, K., Somasundaram, E., Sathyamoorthi, K. and Pazhanivelan, S. (2006) Response of cassava to irrigation scheduling and forage intercropping. Res. J. Agri. Bio. Sci., 2 (6), 559-563.

Awal, M.A., Kothi, H. and Ikeda, T. (2006) Radiation interception and use by maize/peanut intercrop canopy. Agric. For. Meteorol., 139, 73-84.

Bacilio, M., Rodriguez, H., Moreno, M., Hernandez, J.P. and Bashan, Y. (2004) Mitigation of salt stress in wheat seedlings by a gfp-tagged Azospirillum lipoferum. Biol. Fertil. Soils, 40, 188-193.

Barabasz, W., Albinska, D., Jaskowska, M. and Lipiec, J. (2002) Biological effects of mineral nitrogen fertilization on soil microorganisms. Pollut. J. Environ., 11 (3), 193-198.

Bertin, C., Yang, X. and Weston, L.A. (2003) The role of root exudates and allelochemicals in the rhizosphere. Plant and Soil, 256, 67-83.

Bremner, J.M. (1965) Nitrogen availability indexes. In: Methods of Soil Analysis, part 2, Black, C.A. (Ed), Madison, Wisc., ASA, 1324-1345.

Chai, Q., Peng, H. and Bao, H.G. (2005) Effect of intercropping on soil microbial and enzyme activity in the rhizosphere. Acta Prataculturae Sinica, 14, 105-110. 
Carney, K.M., Matson, P.A. and Bohannan, B.J.M. (2004) Diversity and composition of tropical soil nitrifiers across a plant diversity gradient and among land-use types. Ecol. Lett., 7, 684-694.

Cipollini, D.F. (1998) The induction of soluble peroxidase activity in bean leaves by wind-induced mechanical perturbation. Amer. J. Bot., 85, 1586-1591.

Dariush, M., Ahad, M. and Meysam, O. (2006) Assessing the land equivalent ratio (LER) of two corn ( Zea mays L.) varieties intercropping at various nitrogen levels in Karaj, Iran. J. Central European Agric., 7 (2), 359- 364.

Difco (2009) "Manual of Microbiological Culture Media", $2^{\text {nd }}$ ed., Becton, Dickinson and Company parks, Maryland 21152. U.S A.

Dobereiner, J. (1978) Isolation and identification of root associated diazotrophs. Plant Soil. 110, 207.

Dong, L.L., Dong, L.Z. and Qian, W. (2008) Allelopathy of garlic bulb aqueous extracts on cucumber seedling growth. Acta Agric. Boreali Sinica, 23, 47-50.

El-Khawas, H.M. (1995) Indole acetic acid production by natural soil micro-residents. Egypt. J. Appl. Sci., 10 (1), 575-582.

El-Khawas, H.M., Ibrahim, I.A., Anwar, H.M. and Hegazi, N.A. (2000) Isolation and characterization of plant growth-promoting rhizobacteria producing indole-3-acetic acid from plants growing in Egypt. J. Agric. Sci. Mansoura Univ., 25 (10): 64936502 .

Ghazal, F.M., Hassan, E.A. and Nasef, M.A. (2011) Response of wheat plants to EM (Effective Microorganisms) application and/or cyanobacteria inoculation under sandy soil condition. J. Agric. Chem. Biotech., Mansoura Univ., 2 (2), 61-76.

Haas, D. and Défago, G. (2005) Biological control of soil-borne pathogens by fluorescent Pseudomonads. Nature Reviews Microbiology, 3, 307-319.

Hardy, R.W.F., Burns, R.C. and Holsten, R.D. (1973) Applications of the acetyleneethylene assay for measurement of nitrogen fixation. Soil Biol. Biochem., 5, 47-81.

Huang, H.C., Chou, C.H. and Erickson, R.S. (2006) Soil sickness and its control. Allelopathy J., 18, 1-21.

Inal, A., Gunes, A., Zhang, F. and Cakmak, I. (2007) Peanut/maize intercropping induced changes in rhizosphere and nutrient concentrations in shoots. Plant Physiol. Bioch., 45, 350-356.

Jumin, L. and Jin, Z. (2010) Potential allelopathic effects of Mikania micrantha on the seed germination and seedling growth of Coix lacryma-jobi. Weed Biol. Manag., 10, 194-201.

Keswani, C.L., Kibani, T.H.M. and Chowdhury, M.S. (2003) Effect of intercropping on rhizosphere population in maize (Zea mays L.) and soybean (Glycine max Merill). Agri. \& Environ., 3, 363-368.

Egypt. J. Hort. Vol. 42, No. 2 (2015) 
Lai, R.Q., You, M.S., Lotz, L.A.P. and Vasseur, L. (2011) Response of green peach aphids and other arthropods to garlic intercropped with tobacco. Agron. J., 103, 856-863.

Lameei hervan J. (2003) Study on delay intercropping of garlic and bean in Azerbaijan. Proceeding of the $3^{\text {rd }}$ Iranian Horti. Congress. Karaj, Iran, pp. 70 - V6.

Li, L., Yang, S.C., Li, X.L., Zhang, F.S. and Christie, P. (1999) Interspecific complementary and competitive interactions between intercropped maize and faba bean. Plant Soil, 212, 105-114.

Li, L., Sun, J.H., Zhang, F.S., Li, X.L. and Yang, S.C. (2001) Wheat/maize or wheat/soybean strip intercropping. I. Yield advantage and interspecific interactions on nutrients. Field Crops Res., 71, 123-137.

Lixuan, R., Su, S., Yang, X., Xu, Y., Huang, Q. and Shen, Q. (2007) Intercropping with aerobic rice suppressed Fusarium wilt in watermelon. Soil Biol. \& Biochem., 40, 834-844.

Lugtenberg, B. and Kamilova, F. (2009) Plant growth-promoting rhizobacteria. Annual Rev. Microbiology, 63, 541-556.

Mahmoud, A.H.H., El-Kotkat, M.B.O., Omer, M.N.A. and Mostafa, G.A. (2011) Activity of Azolobacter and Azospirillum in the rhizosphere of onion plant. J. Agric. Chem. and Biotech., Moansoura Univ., 2 (10), 229-238.

Mazaheri, D. and Overysi, M. (2004) Effects of inter cropping of two corn vanities at various nitrogen levels. Iranian J. Agronomy, 9,71-76.

Mogahed, M.I. (2003) Influence of intercropping on population dynamics of major insect-pests of potato (Solanum tuberosum) in North Sinai Governorate, Egypt. Indian J. Agr. Sci., 73, 546-549.

Mueller S., Durigan, J.C., Banzatto, D.A. and Kreuz, C.L. (1998) Benefits to yield and profits of garlic and beet intercropping under three weed management epochs. Pesqui Agropecu Bras Pesquisa, 33, 1361-1373.

Olasantan, F.O., Ezumah, H.C. and Lucas, E.O. (1996) Effects of intercropping with maize on the micro-environment, growth and yield of cassava. Agr. Ecosyst. Environ., 57, 149-158.

Olga, G.R., Mejia, E.Z. and Hernandez, V.A.G. (2007) Physiological and morphological adaptations in tomato intercropped with Tagetes erecta and Amaranthus hypochondriacus. Rev. Fitotec. Mex., 30, 421-428.

Oxoid (2006) The Oxoid Manual. $9^{\text {th }}$ ed., by OXOID Limited, Wade Road, Basingstoke, Hampshire RG24 8PW, England, UK.

Ressende, B.L.A. (2000) Productivity of lettuce and radish cultivations as a function of spacing and time of establishment of intercropping. ISHS Acta Hort. International symposium on timing of field proudtion in Vegetable crops. 607. 
Selim, A.E.I. and El-Saei, M.A. (2001) Effect of composed inoculation with $\mathrm{N}_{2}$-fixing bacteria and vesicular-arbuscular mycorrhiza on growth and nutrition of Mung bean. J. Agric. Sci. Mansoura Univ., 26 (5), 3085-3097.

Siddiqui, Z.A. (2004) Effects of plant growth promoting bacteria and composed organic fertilizers on the reproduction of Meloidogyne incognita and tomato growth. Bioresource Technology, 95, 223-227.

Sivaraman, K. and Palaniappan, S.P. (1996) Turmeric-Maize and onion intercropping systems. III. Nutrient uptake. J. Spices Aromatic Crops, 5(1): 49-57.

Snedecor, G.W. and Cochran, W.G. (1989) "Statistical Methods", $8^{\text {th }}$ ed. $2^{\text {nd }}$ Printing. Lowa State Univ. Press, Ames, USA.

Sofi, P. and Wani, S. (2007) Prospects of nitrogen fixation in rice. Asian J. Plant Sci., 6, 203-213.

Song, Y.N., Zhang, F.S., Marschner, P., Fan, F.L., Gao, H.M., Bao, X.G., Sun, J.H. and Li, L. (2007) Effect of intercropping on crop yield and chemical and microbiological properties in rhizosphere of wheat (Triticum aestivum L.), maize (Zea mays L.) and faba bean (Vicia faba L.). Biol. Fert. Soils, 43 (5), 565-574.

Sturz, A.V. and Christie, B.R. (2003) Beneficial microbial allelopathies in the root zone: The management of soil quality and plant disease with rhizobacteria. Soil and Tillage Res., 72, 107-123.

Sutton, S. (2010) The most probable number method and its uses in enumeration, qualification and validation. J. Validation Technology, 35-38.

Uren, N.C. (2000) Types, amounts, and possible functions of compounds released into the rhizosphere by soil-grown plants. Biochemistry and Organic Substances at the Soil-Plant Interface, pp. 19-40.

Vessey, K.J. (2003) Plant growth promoting rhizobacteria as bioferitilizers. Plant Soil, 255, 571-586.

Wang M., Wu, C., Cheng, Z., Meng, H. and Zhang, M. (2014) Soil chemical property changes in eggplant/garlic relay intercropping systems under continuous cropping. Plos one 9 (10): e111040. doi:10.1371/ journal. pone.0111040.

Winton, A.L. and Winton, K.B. (1958) The Analysis of Foods. John Wiley \& Sons. Inc. Londan, 857p.

Wu, H., Yun, K. and Yuncong, Y. (2010) Effects of intercropping aromatic plants on soil microbial quantity and soil nutrients in pear orchard. China Agri. Sci., 43, 140150 .

Xiao, X.M., Cheng, Z.H., Meng, H.W., Khan, M.A. and Li, H.Z. (2012) Intercropping with garlic alleviated continuous cropping obstacle of cucumber in plastic tunnel. Acta Agr. Scand. B-SP, 62 (8), 696-705. 
Ye, S.F., Yu, J.Q. Peng, Y.H. Zheng, J.H. and Zou, L.Y. (2004) Incidence of Fusarium wilt in Cucumis sativus L. is promoted by cinnamic acid, an autotoxin in root exudates. Plant Soil, 263, 143-150.

Yildirim, E., Taylor, A.G. and Spittler, T.D. (2006) Ameliorative effects of biological treatments on growth of squash plants under salt stress. Scientia Horticulturae. 111, 16.

Zhang, J.E., Gao, A.X., Xu, H.Q. and Luo, M.Z. (2009) Effects or maize/peanut intercropping on rhizosphere soil microbes and nutrient contents. Chinese J. App. Eco., 20, 1597-1602.

Zheng, Y., Zhang, F. and Li, L. (2003) Iron availability as affected by soil moisture in intercropped peanut and maize. J. Plant Nutr., 26, 2425-2437.

Zhou, Y.L., C.Z. Hui, M.H. Wen and Chun, G.H. (2007) Allelopathy of garlic root aqueous extracts and root exudates. J. Northwest A \& F Univ., 35, 87-92.

Zhou, X.G., Yu, G.B. and Wu, F.Z. (2011) Effects of intercropping cucumber with onion or garlic on soil enzyme activities, microbial communities and cucumber yield. Eur. J. Soil Biol., 47, 279-287.

(Received 8 / 10/2014; accepted 10/2/2015) 


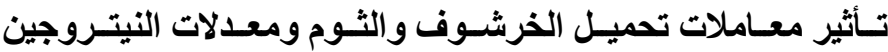

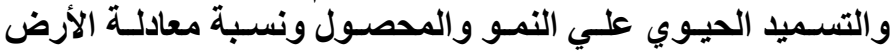 والمحتوي الميكروبي في ريزوسفير نبات الخرشوف}

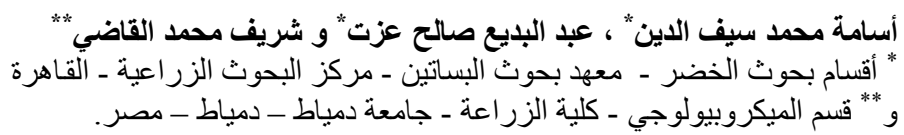

